\title{
CHEMICAL RELEASERS OF SOCIAL BEHAVIOR. $X$. AN ATTINE TRAIL SUBSTANCE IN THE VENOM \\ OF A NON-TRAIL LAYING MYRMICINE, DACETON ARMIGERUM (LATREILLE) ${ }^{1}$.
}

\author{
By M. S. BLuM ${ }^{2}$ \\ and \\ C. A. Portocarrero ${ }^{2,3}$
}

Although the poison gland secretion may provide species in several myrmicine genera with a readily available source of odor trail pheromone, this venom does not represent a highly species-specific secretion. It has been demonstrated recently that odor trails prepared from extracts of the poison gland are non-specific even among unrelated genera, although specificity may be absolute when these extracts are tested on species in the same genus (Blum and Ross, 1965). The lack of specificity of the poison gland extracts appears to be due to the fact that trace constituents, which are common to different venoms, are employed by different genera as odor trail releasers. Thus, although members of two genera may be employing different trail substances, they will follow trails prepared from each other's poison glands because their odor trail compounds are present in both venoms. Since some of the trace compounds in the venoms synthesized by unrelated trail-laying myrmicines appear to be similar, it would not be surprizing if the venom of a non-trail laying species contained a trace constituent which was the same as the odor trail pheromone employed by trail-laying members of this subfamily. The purpose of this present paper is to report on the occurrence of just such a case. Daceton armigerum (Latreille) a primitive member of the tribe Dacetini, contains in its venom a powerful releaser of trail following for members of three attine genera as well as for an inquiline cockroach which is associated with one of these genera.

The biology of Daceton has been studied in detail by Wilson (1962). Daceton workers hunt singly and no evidence of trail laying or recruitment was observed either in the field or in the laboratory. The large eyes of Daceton workers appear to endow them with

\footnotetext{
${ }^{1}$ This work was supported in part from two grants from the University Council on Research of Louisiana State University

${ }^{2}$ Department of Entomology, Louisiana State University, Baton Rouge, Louisiana.

${ }^{3}$ Present address: Department of Communications, Michigan State University, East Lansing, Michigan.

Manuscript received by the editor June 29, 1966.
} 
Table I. Response of attine species and a species of Attaphila to artificial trails prepared from extracts of the poison gland of Daceton armigerum.

\begin{tabular}{|l|c|c|}
\hline \multicolumn{1}{|c|}{ Test species } & $\begin{array}{c}\text { No. of workers } \\
\text { tested }\end{array}$ & $\begin{array}{c}\text { No. of workers } \\
\text { responding }\end{array}$ \\
\hline Daceton armigerum & IOO & 0 \\
Trachymyrmex septentrionalis & 100 & 90 \\
Acromyrmex coronatus & IOO & 87 \\
Acromyrmex nr. coronatus & 100 & 94 \\
Sericomyrmex urichi & 60 & 0 \\
Atta texana & 100 & 73 \\
Atta cephalotes & 100 & 82 \\
Attaphila sp. & 30 & 28 \\
\hline
\end{tabular}

exceptional vision and they are able to pursue their prey for considerable distances (Wilson, 1962).

The two colonies of Daceton that Wilson studied were strictly aboreal and in no instance did he see workers move from the trees to the ground. However, in the single Daceton colony which we observed we noted three workers on the leaf litter adjacent to the base of their nest tree, making no apparent effort to forage on the leaves, and two other workers some distance from their colonial tree. Under the nest tree there were two small shrubs separated from the overhanging tree by at least three feet. A Daceton worker was resting on each shrub. These workers only could have reached these shrubs by walking across the leaf litter under their nest tree or by falling from the tree onto the shrubs. These observations suggest that under certain conditions Daceton workers may not be totally arboreal.

\section{METHODS AND MATERIALS}

A nest of Daceton was located in a large tree in a nursery at Buenos Aires, 25 kilometers south of Pucallpa, Peru, near the Rio Ucayalli. The colony consisted of three fragments in two branches of the tree. Approximately 600 workers were collected from the nest and were transported to Pucallpa for odor trail studies. Their poison glands were extracted in absolute ethanol. These ethanolic extracts were employed for preparing circular trails (Moser and Blum, 1963) and Daceton and Atta cephalotes (L.) ${ }^{4}$ workers were tested on these trails. The living Daceton workers were transferred

\footnotetext{
${ }^{4}$ Collected at Pucallpa, Peru.
} 
to Tingo Maria, where further artificial trail testing was performed using chloroform solutions of the Daceton poison glands. The following species were also tested on the trails: Acromyrmex coronatus (F.) ${ }^{5}$, Acromyrmex nr. coronatus (F.) ${ }^{5}$, and a cockroach, Attaphila sp. ${ }^{5}$, which was found in the fungus garden of $A$. coronatus.

The Daceton workers then were frozen and packed in dry ice for air transport to the United States. Workers of Trachymyrmex septentrionalis $(\mathrm{McCook})^{6}$, Sericomyrmex urichi Forel ${ }^{7}$, and Atta texana (Buckley) ${ }^{8}$ were tested on artificial trails prepared from methylene chloride solutions of poison glands dissected from the frozen Daceton workers.

\section{RESULTS}

Although Daceton workers do not follow artificial trails prepared from their own poison gland secretion, these trails release strong trail following in attine members of the genera Trachymyrmex, Acromyrmex, and Atta (Table I). On the other hand, workers of Sericomyrmex urichi did not follow trails prepared from the venom of Daceton. The concentration of the attine odor trail pheromone in the venom of Daceton appears to be the same as it is in the venoms of the attines. Extracts which were prepared from Daceton and Atta poison glands of equivalent size exhibited about the same odor trail potencies after serial dilution.

It is quite likely that the Attaphila are responding to the same compound in the vencm of Daceton as are the attines. Moser (1965) has shown that Attaphila fungicola Wheeler will follow artificial trails prepared from the venom of both $A$. texana and $T$. septentrionalis. Although Moser reported that $A$. texana workers were more sensitive to the odor trail pheromone than the cockroaches, we noted that the Attaphila held to the artificial trails much more tenaciously than the ant workers in any of the genera.

Since Sericomyrmex urichi did not follow artificial trails prepared from the venom of Daceton, we wished to determine whether or not this attine would respond to artificial trails prepared from the poison glands of other attines and vice versa. Assuming that the venom of Daceton contains a compound which is similar to those employed by several of the attine genera as trail substances, then

\footnotetext{
${ }^{5}$ Collected at Tingo Maria, Peru.

${ }^{8}$ Collected at Baton Rouge, Louisiana.

${ }^{7}$ Collected at Trinidad by Prof. Neal A. Weber, Department of Biolegy, Swarthmore College, Swarthmore, Pa.

${ }^{8}$ Collected at Pineville, Louisiana.
} 
Table 2. Numbers of Sericomyrmex, Trachymyrmex, and Atta workers responding to the poison gland secretion in the artificial test. Number of replications in parentheses ${ }^{9}$. Test species

\begin{tabular}{|l|c|c|c|}
\hline \multicolumn{1}{|c|}{ Source species } & $\begin{array}{c}\text { Sericomyrmex } \\
\text { urichi }\end{array}$ & $\begin{array}{c}\text { Trachymyrmex } \\
\text { septentrionalis }\end{array}$ & $\begin{array}{c}\text { Atta } \\
\text { texana }\end{array}$ \\
\cline { 2 - 2 } $\begin{array}{c}\text { Sericomyrmex urichi } \\
\text { Trachymyrmex } \\
\text { septentrionalis }\end{array}$ & $78(8)$ & $\mathrm{O}(8)$ & $4 \mathrm{O}(\mathrm{IO})$ \\
Atta texana & $\mathrm{IO}(8)$ & $9 \mathrm{O}(8)$ & $9 \mathrm{I}(\mathrm{IO})$ \\
$\mathrm{O}(8)$ & $88(8)$ & $96(\mathrm{IO})$ \\
\hline
\end{tabular}

the failure of Sericomyrmex to follow Daceton trails would indicate that its trail pheromone was different from those of the other attines. Circular trails were prepared from extracts of the poison glands of $S$. urichi, $T$. septentrionalis and $A$. texana, and the response of workers of each species to the trails was determined. The results, presented in Table 2, demonstrate that $S$. urichi does not follow the odor trails of $A$. texana or $T$. septentrionalis. Similarly, the trail substance in the poison gland secretion of Sericomyrmex releases virtually no trail following in workers of $T$. septentrionalis and is only slightly active when tested with workers of $A$. texana (Table 2).

\section{DISCUSSION}

Although Daceton armigerum does not lay odor trails, its venom contains a substance which is either similar or identical to the trail pheromones employed by attines in the genera Trachymyrmex, Acromyrmex, and Atta. In all probability this substance is a trace constituent of the poison gland secretion produced by Daceton. The venom of Daceton is rich in proteins which solidify when the poison vesicle is ruptured in the air. An attine odor trail pheromone can be readily extracted from the solidified venom without a measurable weight loss occurring and it is probable that a trace component is being removed during the extraction process. Similarly, the odor trail pheromones can be extracted from the solidified attine venoms without causing any detectable weight loss in the venomous residues. The attine venoms, like that of Daceton, are rich in proteins but in addition, the poison gland secretions of the attines contain large series of free amino acids which cannot be detected in the venom of Daceton.

More evidence that the venom of Daceton contains an attine odor trail pheromone is derived from the fact that the Attaphila follow

\footnotetext{
${ }^{9}$ Ten workers per replicate.
} 
the artificial Daceton trails. Moser (1965) has demonstrated that another cockroach species, Attaphila fungicola, follows artificial attine trails, and Echolls (1965) has seen this cockroach on trails of $A$. texana in the earīy morning ( $\mathrm{I}$ a.m.) Obviously these blattids can maintain a close association with their Atta hosts because of their ability to follow the odor trails of the ants. Thus, since members of the genus Attaphila appear to be following the same trail substance as the attines employ, these cockroaches would be expected to follow artificial Daceton trails if their venom contained an attine trail pheromone. It should be added that the Attaphila also follow artificial trails of both Acromyrmex species, as they would be expected to do.

The evidence concerning Sericomyrmex is also circumstantial but is equally persuasive. Previously it had been shown that there was no specificity in the trail substances produced by four attine genera which encompassed the broad phylogenetic spectrum of the tribe Attini (Blum et al., 1964). Since these attines follow each other's odor trails, then they would be expected to follow the artificial Daceton trails if these trails contained a substance which was chemically similar to their apparently common odor trail pheromones. On the other hand, if an attine produced a trail substance which was different from the one being employed by these several attine genera, then this attine would respond neither to the artificial trails of these other attine genera nor to the Daceton trail. Sericomyrmex urichi is the first member of an attine genus which has been shown not to respond to the artificial trails prepared from the poison gland secretions of other attine genera. Weber ( 1966) considers Sericomyrmex a somewhat aberrant member of the higest genera and it is certainly distinguished from at least two of the other higher attine genera by this apparent employment of a different trace constituent as an odor trail pheromone.

The other gland associated with the sting, Dufour's gland, also has been shown to be an unexpected source of a myrmicine trail pheromone. Wilson and Pavan ( I959) reported that the Dufour's gland secretion of the dolichoderine Monacis bispinosa (Olivier) contained a powerful trail substance for the fire ant Solenopsis saevissima (Fr. Smith) which produces its trail substance in Dufour's gland. However, M. bispinosa synthesizes its own trail pheromone in Pavan's gland, a special organ which lies on the sixth abdominal sternite. Thus the function of the Dufour's gland secretion in $M$. bispinosa is completely unknown but it is obviously not employed for laying odor trails. It seems eveident that $M$. bispinosa, like Daceton, pro- 
duces some natural products in its sting-associated glands which are also produced by msmbers of the Myrmicinae. It is not unlikely that the natural products' chemistry of the glands associated with the ant sting will continue to be characterized by the presence of common products, some of which are employed as trail substances. Under these circumstances we may anticipate that the Formicidae will continue to be a rich source of unsuspected trail substances whose specificities will be at best, unpredictable.

\section{SUMMARY}

Artificial trails prepared from the poison gland of Daceton armigerum (Latreille), a myrmicine which does not lay odor trails, cause trail following in attine species in the genera Trachymyrmex, Acromyrmex, and Atta. An inquiline cockroach, Attaphila sp., also follows trails prepared from the venom of Daceton. The poison gland secretion of Daceton apparently contains a trace constituent which is similar or identical to the odor trail pheromone used by these attine genera. An attine species in the genus Sericomyrmex responds neither to artificial Daceton trails nor the odor trail pheromones of Atta or Trachymyrmex.

\section{REFERENCES}

Blum, M. S., J. C. Moser, and A. D. Cordero.

1964. Chemical releasers of social behavior. II. Source and specificity of the odor trail substances in four attine genera. (Hymenoptera: Formicidae). Psyche 71: 1-7.

BLUM, M. S. and G. N. Ross.

1965. Chemical releasers of social behaviour. V. Source, specificity and properties of the odour trail pheromone of Tetramorium guineense

Echolls, W. H.

(F.). Formicidae: Myrmicinae). J. Insect Physiol. 11: 857-868.

1965. Private communication.

Moser, J. C.

1964. Inquiline roach responds to trail-marking substance of leaf-cutting ants. Science 143: 1048-1049.

Moser, J. C. and M. S. Blum.

1963. Source and potency of the trail marking substance of the Texas leaf-cutting ant. Science 140: 1228.

WEber, N. A.

1966. Private communication.

WILson, E. O.

1962. Behavior of Daceton armigerum (Latreille) with a classification of self-grooming movements in ants. Bull. Mus. Comp. Zool. 127: 403-421.

Wilson, E. O. and M. Pavan.

1959. Glandular sources and specificity of some chemical releasers of social behavior in dolichoderine ants. Psyche 66: 70-76. 

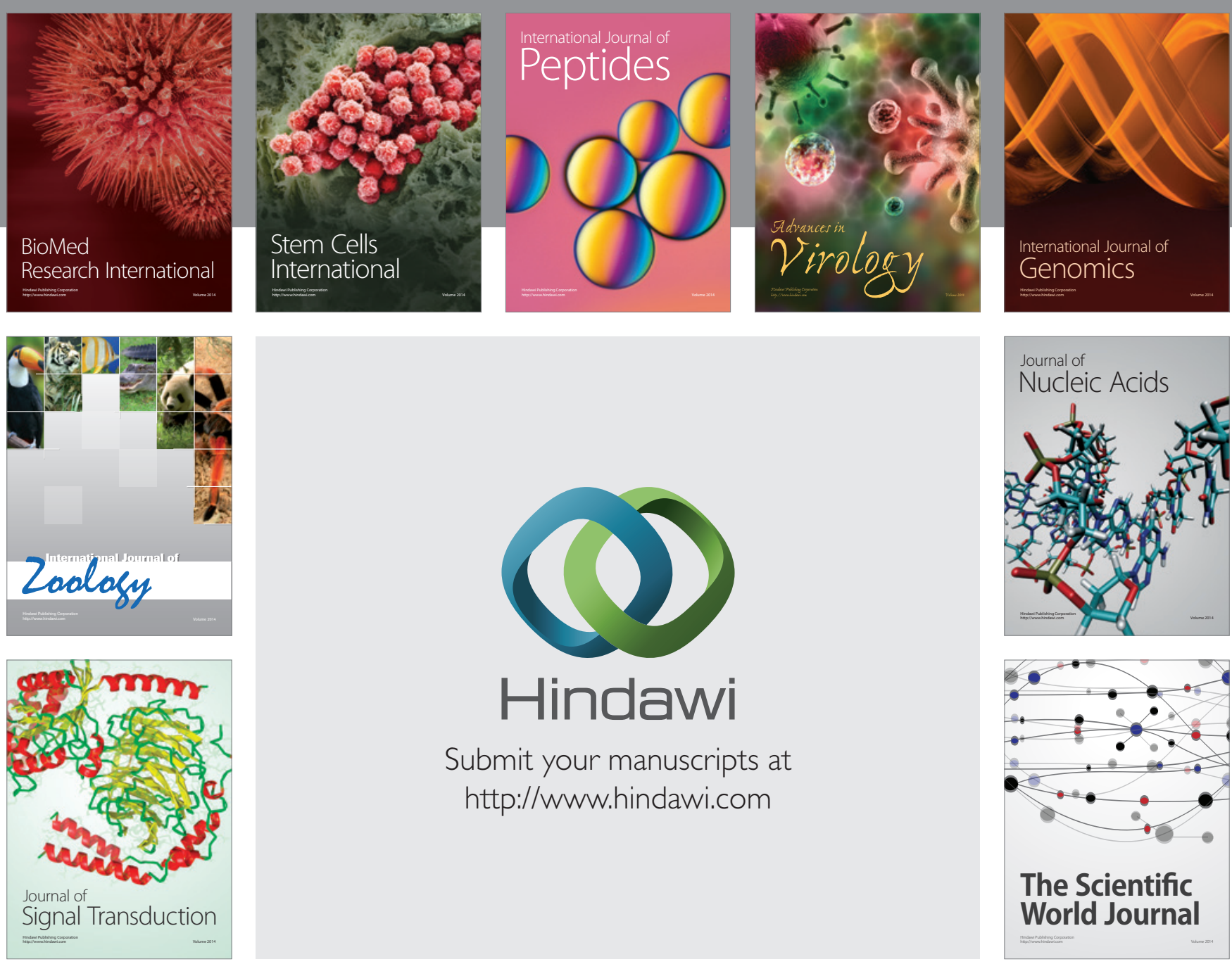

Submit your manuscripts at

http://www.hindawi.com
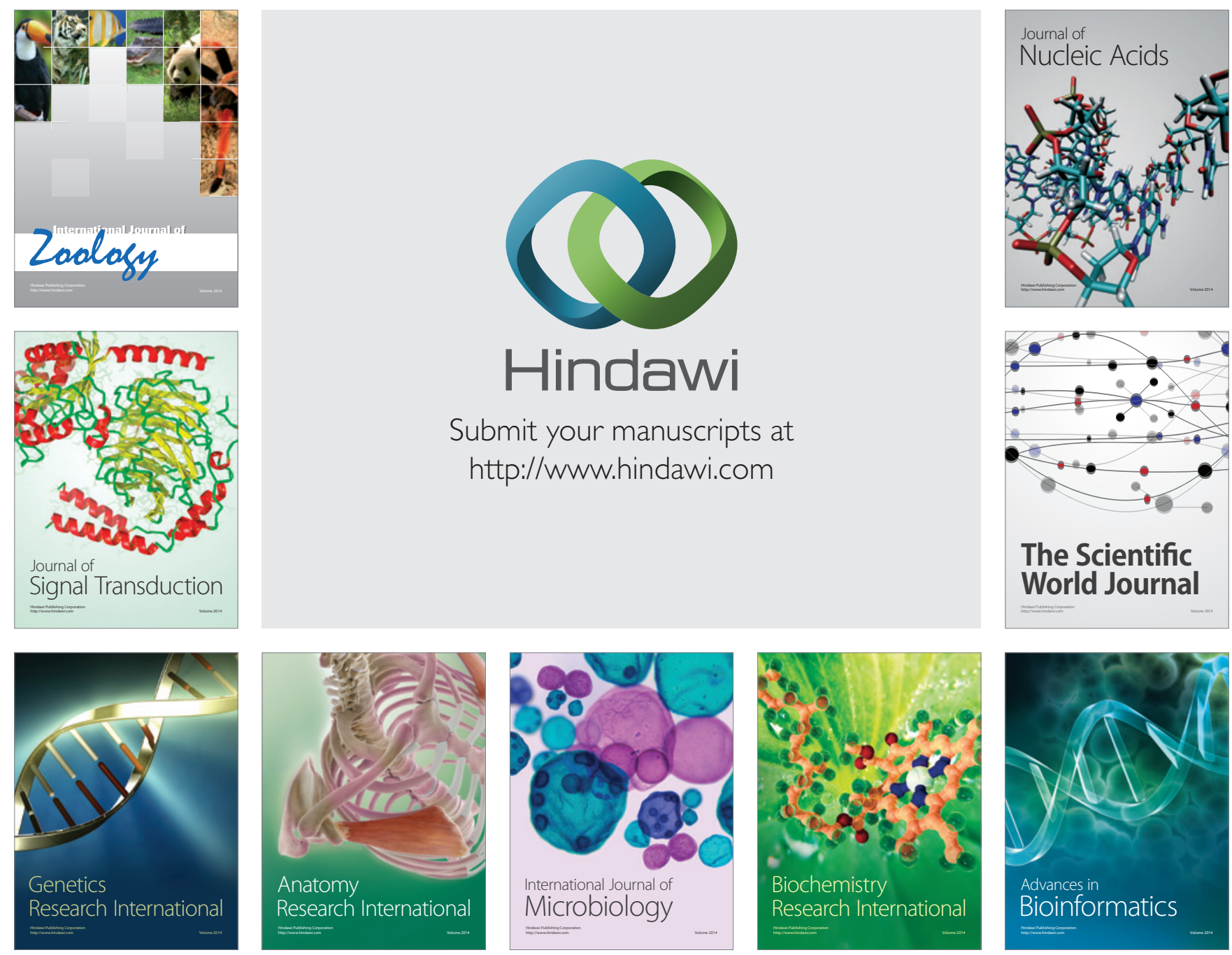

The Scientific World Journal
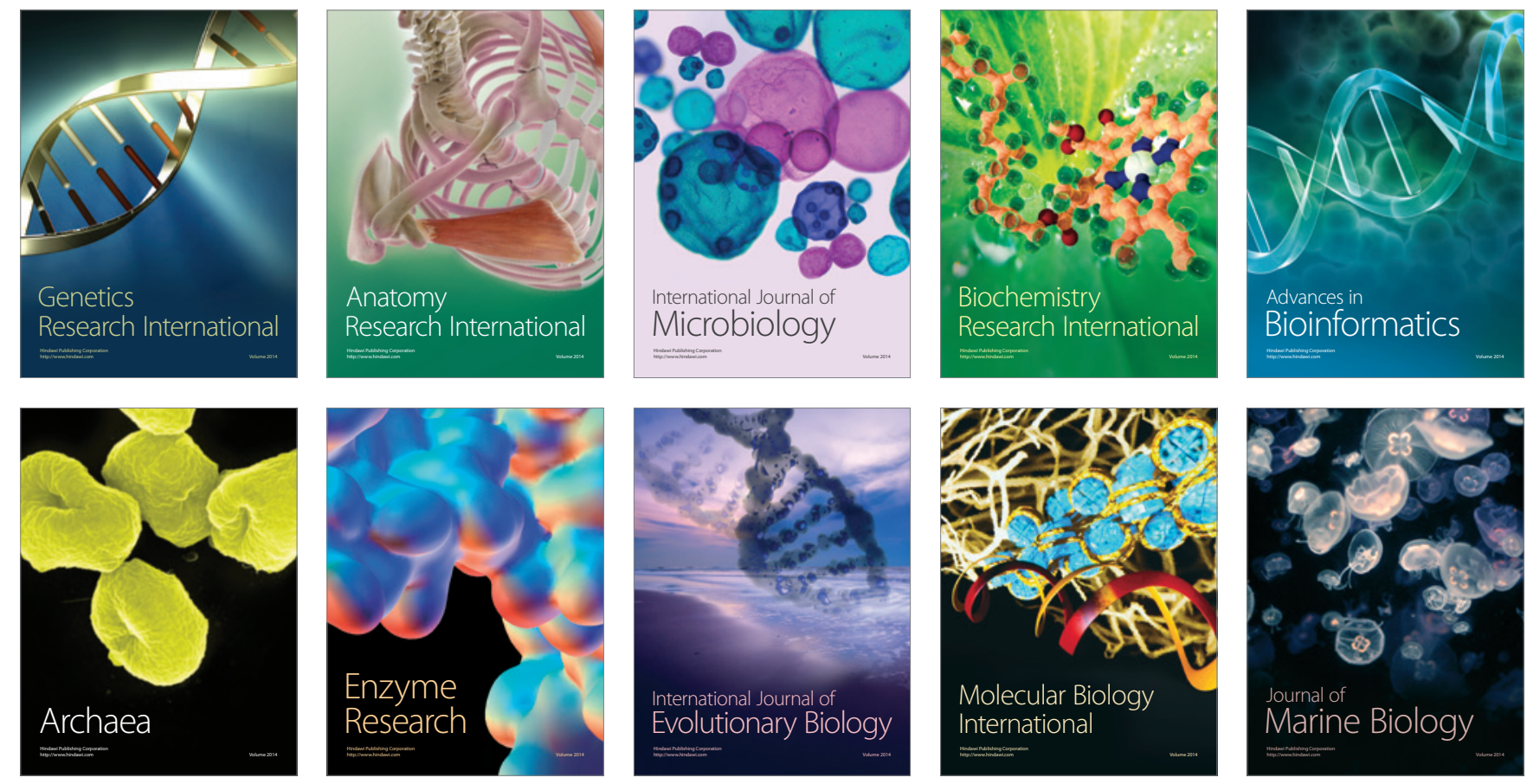